\title{
Citizenship, integration and the quest for social cohesion: nationality reform in the Scandinavian countries
}

\author{
Arnfinn H Midtbøen
}

\author{
Correspondence: a.h.midtboen@ \\ socialresearch.no \\ Institute for Social Research, PO Box \\ 3233, Elisenberg N-0208 Oslo, \\ Norway
}

\begin{abstract}
After having coordinated their nationality laws since the late 19th century, the Scandinavian countries have moved in distinctly different directions in this field since the turn of the millennium. Today Sweden has one of the most liberal citizenship policies in Europe, while Denmark has one of the most restrictive. Norway occupies an intermediate position between its Scandinavian neighbours. In this article, I compare the differences in Scandinavian nationality law and the political processes that led to these changes. The highly divergent development of nationality law in the Scandinavian region questions the widespread idea that a general convergence towards liberalization of European nationality law is taking place. Although static concepts of nationhood cannot account for the recent changes in Scandinavian nationality law, ideas about national identity and social cohesion are still highly influential in determining the content of nationality law.
\end{abstract}

Keywords: Citizenship; Nationality reform; Immigration; Integration; Social cohesion

\section{Background}

Norway, Sweden and Denmark share a long tradition of cooperation with regard to citizenship acquisition. Ever since the countries adopted their first nationality legislations in the late 19th century, they sought to achieve parity in their legislative regulations (Nordhaug, 2000). As late as 1945, there was an explicit desire to establish the region as a common citizenship unit, with identical rules and free movement across the borders for citizens. Although this vision was never realized, the 1950 nationality acts that came into force in Norway, Sweden and Denmark at the same time were founded on a common Scandinavian outlook, and in practice entailed identical legislative regulations (Ersbøll, 2003).

The historic Scandinavian cooperation in the field of nationality legislation is unique in the European context. Citizenship law and naturalisation policies in Europe have historically been characterized by extensive national dissimilarities, and forms of cooperation between national authorities have rarely taken place (Brubaker, 1989). This has often been explained by referral to citizenship as closely related to national sovereignty: Citizenship law is an institutional expression of the right of a state to include or exclude potential new members in the national community (Hansen \& Weil, 2001). The dissimilarities between European states in the field of citizenship have also been

(c) 2015 Midtbøen; licensee Springer. This is an Open Access article distributed under the terms of the Creative Commons Attribution License (http://creativecommons.org/licenses/by/4.0), which permits unrestricted use, distribution, and reproduction in any medium, provided the original work is properly credited. 
explained by what Brubaker (1992) refers to as different conceptions of nationhood, i.e. fundamental conceptions of what constitutes a nation (see also Favell, 1998). According to Brubaker, conceptions of nationhood are embedded in the political and cultural history of a country, and manifest themselves in fundamentally different attitudes to the inclusion of newcomers through rules for acquisition of citizenship.

In recent years, the use of nationhood as a starting point for analyses of citizenship development has been criticized for regarding nationality legislation as determined by historical traditions (Joppke, 2007; Perchinig \& Bauböck, 2006). Since the mid-1990s, significant changes have occurred in European nationality law, and in many cases these changes represent clear discontinuities with regard to old traditions. Some authors observe a convergence towards a general liberalization, in which civic virtues are claimed to have replaced old-fashioned ethno-nationalism (e.g. Hansen \& Weil, 2001; Joppke, 2007). Others, however, point out that a more restrictive trend has been established, and that national differences remain the most prominent feature of European nationality law (Bauböck, Ersbøll, Groenendijk, \& Waldrauch, 2006). Recently, it has even been claimed that the whole idea of a discontinuity of citizenship policies must be re-examined, as it is resilience rather than change that characterizes citizenship traditions in western Europe (Mouritsen, 2013).

How do the recent changes of nationality legislation in the Scandinavian countries fit into this contradicting picture of citizenship development in Europe? After nearly one hundred years of efforts to achieve equality in the field of nationality law, the Scandinavian cooperation was brought to an end in 1979. In the subsequent period, Sweden, Denmark and Norway have gradually moved in different directions. In 2001, Sweden adopted a new citizenship act that contrasts with previous Scandinavian practices, for example by accepting dual citizenship. Since 2001, Denmark on the other hand has implemented a series of highly restrictive changes, making the country one of the most restrictive in Europe in the field of citizenship policies. Norway adopted a new nationality act in 2005. This act embodies liberal as well as restrictive tendencies, and positions Norway between its Scandinavian neighbours.

In this article, I compare the current nationality laws in the Scandinavian countries, as well as the political processes that generated the changes occurring in the early 2000s. The main emphasis is on the question of dual citizenship and regulations associated with time of residence, citizenship ceremonies and oaths of allegiance, as well as any requirements for language skills, knowledge of society and financial self-sufficiency forming conditions for naturalization. The legislative changes are then discussed in light of a wider socio-political context: First, by pointing out how changes in nationality law correspond to the divergent approaches to integration policy that have been taken by Sweden, Denmark and Norway during recent years. Second, by discussing how the linkage between citizenship and integration in various ways appears to embody the ongoing quest for social cohesion within European multicultural nation-states today. The highly divergent development of nationality law in the Scandinavian region suggests that no general convergence towards liberalization is taking place.

\section{Results}

\section{Nationality reform in the Scandinavian countries}

For nearly one hundred years, Sweden, Denmark and Norway collaborated to establish homogeneity in the nationality legislation prevailing in the Scandinavian region. 
Throughout this period, the laws in all three countries were based on the jus sanguinis principle in the automatic acquisition of citizenship at birth, ${ }^{\mathrm{a}}$ and on the principle that immigrants had to renounce their previous citizenship if they wanted to become citizens of one of the Scandinavian countries. This latter requirement was based on the desire to avoid cases of dual citizenship, a principle that has been reflected in international law throughout most of the 20th century (Hailbronner, 2006).

The 1997 European Council Convention entails a radical departure from this legal notion. Here, the governments are left free to decide whether or not they should accept dual citizenship, and the Convention also represents the most comprehensive and complete collection of basic principles available in the field of nationality law internationally. One main objective was to contribute to a harmonization of nationality legislation in the European region (Hailbronner, 2006). Sweden, Denmark and Norway have all ratified the convention, and a comparison of the nationality laws in the three countries thereby provides an indication of whether a European convergence has taken place.

\section{Sweden breaks away}

The Swedish Citizenship Act came into force on 1 July 2001, replacing the existing act from 1950. Even though the new act in many ways is based on tradition and continuance of previous regulations, it also contains distinct features that depart from previous practices, and a number of its aspects testify to a new and more inclusive attitude to immigrants who are permanently resident in the country (H. Bernitz, 2012; H. L. Bernitz \& Bernitz, 2006).

In 1997, a committee was charged with the study of issues associated with the Swedish nationality legislation, as well as assessment of measures that could strengthen the status of citizenship as an instrument for integration policy. In the wake of the European Council Convention of 1997, the committee in 1998 received additional instructions, requiring the members to consider the issue of dual citizenship. The committee's report (SOU 1999:34) is characterized by general liberalization and a strengthening of individual rights at the cost of state prerogatives. This becomes especially clear in the committee's discussion of advantages and disadvantages of dual citizenship. The most prominent problems - the right to vote and eligibility in several countries, difficulties associated with consular assistance and military draft, as well as concerns for security following from conflicting loyalties - are regarded as being of minor importance compared to the practical advantages and the emotional security offered to the individual as a consequence of the amendment to the act. The conviction that dual citizenship in this context could serve to 'contribute to improved well-being and a more rapid integration in the new society' (SOU 1999:34, p. 203) b $^{\text {b }}$ reflects the pervasive tendency in the Swedish public documents to point out the correlation between citizenship and social integration.

Individuals who have immigrated to Sweden can apply for Swedish citizenship through naturalization. According to the new act, aspiring citizens must document their identity, be at least 18 years of age, possess a permanent residence permit in Sweden and have been resident in the country for the last five years. ${ }^{\mathrm{c}}$ The only tightening of the conditions for naturalization compared to previous practice is found in the requirement for permanent residence. When combined with the significant opportunities for exemptions, especially with regard to ID documents and time of residence, it is fair to conclude that Swedish naturalization policies are highly liberal. For example, the 
requirement for financial self-sufficiency was abolished in 1976, and shortly after, the language proficiency requirement was also abolished and the required time of residence reduced from seven to five years (H. L. Bernitz \& Bernitz, 2006). Neither are there any requirements relating to knowledge of Swedish society in the context of obtaining Swedish citizenship, and no oath of allegiance to the Swedish state or constitution is required.

A key aspect of the committee's mandate was to assess how the status of citizenship could be raised as part of the integration process. In this context, requirements for language proficiency and knowledge of Swedish society were reviewed as possible measures that could be used to enhance the integrative effect of citizenship. Although the committee held language proficiency to be essential for all permanently resident inhabitants, it concluded that citizenship should not be made conditional on such requirements for language skills or knowledge of society. The reason given for this conclusion was a fear of an elitization of the institution of citizenship. Such requirements would have unequal effects for individuals and could imply that some applicants would need more time to qualify for Swedish citizenship, and some could even become excluded from this opportunity as whole:

The committee regards citizenship as a pathway to social cohesion and as a link in the integration process. Raising the requirements for qualification would be likely to produce the opposite effect, meaning that the nation's total sense of cohesion would be reduced (SOU 1999:34, p. 318).

The above passage illustrates the committee's views on this issue. Rather than setting requirements, the dominant attitude is that the immigrants themselves are responsible for learning Swedish, and they are expected to do their best on the basis of their individual skills. In general, it is assumed that persons who apply for naturalization have obtained sufficient knowledge of Swedish society and language based on the time of residence required.

One measure that was proposed to enhance the status of citizenship involved the arrangement of ceremonies to celebrate completed naturalization. Even though there is no tradition for this practice in Sweden, several Swedish municipalities have taken the initiative to welcome their new citizens in this manner. The committee claims that such ceremonies should be arranged because it would represent a positive signal from Swedish society, but points out that it is in 'the nature of the matter' that participation must be voluntary and that the municipalities cannot be required to undertake such arrangements (SOU 1999:34, p. 328). Consequently, this resulted in just a general recommendation, and the arrangement of ceremonies is not defined in the current act. Today, it is discussed whether citizenship ceremonies should be compulsory for the local authorities to arrange, but this is yet to be decided (H. Bernitz, 2012).

Summing up, important changes in citizenship policies have taken place in Sweden compared to the 1950 act. Immigrants who are legally resident enjoy basically the same social, civil and economic rights as the remaining population, they were given the right to vote and eligibility in local elections as early as 1976, and the new act adopted in 2001 established acceptance of dual citizenship as official Swedish practice. When combined with the enduring idea of citizenship as an instrument for integration and the recurring references to international conventions in the preparatory documents for the act, it is fair to conclude that concerns for individual rights have gained pre-eminence 
over traditional notions of national identity. This does not necessarily imply, however, that national identity has lost its meaning in the Swedish context. Rather, the changes in Swedish nationality law may demonstrate a national identity characterized by 'humanitarian internationalism': The new nationality act was initiated by a desire to modernize legislation in the wake of immigration and internationalization, and the act can be regarded as a reflection of more recent perceptions of Sweden as a multicultural society.

\section{Denmark's restrictive turn}

The new Swedish Citizenship Act from 2001 represented a departure from Scandinavian and later Nordic - cooperation in the field of nationality legislation. Although formal cooperation ceased in 1979, consultations between the Nordic countries have taken place when amendments have been enacted. Sweden's initiative for a legal reform and the preparatory work undertaken by the Swedish committee was, however, undertaken without any Nordic consultations. ${ }^{d}$ The new Swedish attitude to the question of dual citizenship spurred an immediate change in Danish legislation: Since 2002, all Nordic citizens are required to document that their previous citizenship has been dissolved before they can be naturalized in Denmark, exactly like all other foreign nationals (Ersbøll, 2013). ${ }^{\mathrm{e}}$ This tightening of the special regulations for Nordic citizens has taken place in parallel with other steps taken in a more restrictive direction in Danish nationality legislation in general. Citizenship is regarded as the culmination of successful integration, and has increasingly become a more exclusive privilege. The requirements imply that Denmark currently has one of the most restrictive regulations of citizenship in Europe.

While all the Nordic countries (including Iceland and Finland) have reformed their rules for citizenship acquisition during the 2000s, the 1950 act remains in force in Denmark. The freedom provided by the European Council Convention to decide whether to accept dual citizenship or not has furthermore been met with a continuously negative attitude to this status. In Denmark, the debate in the parliament (Folketinget), subsequent to the adoption of the new Swedish act, was characterized by a completely different notion of national affiliation than what had been observed in Sweden: Citizenship was regarded as unique and indivisible, and the dissolution of applicant's previous citizenship was referred to as a key mechanism for establishment of identity, which is required to maintain a social and cultural community (Holm, 2006).

The most prominent changes in Danish nationality legislation concern the requirements for naturalization. While these requirements are spelled out explicitly in the legal acts in Sweden and Norway, the Danish requirements for naturalization are defined in guidelines (called 'Circulation Documents' or cirkulcereskrivelser) issued by the Ministry of Refugees, Immigrants and Integration. The guidelines are subject to negotiation and are decided by the political parties that command the majority in the parliament. Between 2001 and 2011, the majority consisted of the right-wing parties Liberal Party of Denmark, The Conservatives and The Danish People's Party. Between 2001 and 2007, a number of new and more restrictive guidelines were issued.

Circular Document No. 55 of 2002 (Danish Ministry of Refugees, Immigrants and Integration 2002) presented several new requirements: First, an oath of allegiance was introduced, as a condition for naturalization, in which applicants must "swear allegiance and loyalty to Denmark and Danish society, and declare that [they] will abide by the 
laws of Denmark and respect basic Danish legal principles" (Section 2). Second, the required time of residence was increased from seven to nine years (Section 7). ${ }^{\mathrm{f}}$ Third, the requirements for conduct were tightened, so that applicants who have been expelled from the country or who have been sentenced to prison terms of two years or more, are excluded from naturalization for life (Section 19). Finally, a requirement regarding Danish language proficiency and familiarity with Danish society, history and culture was introduced, to be documented by a separate examination (Section 25). However, the language requirement did allow for certain exemptions so that persons suffering from mental or physical illnesses could be exempt on the basis of a medical certificate.

In the 2005 election, the Danish People's Party strengthened its position in relation to the other right-wing government parties, and was invited back to negotiations concerning immigration policy by Prime Minister Anders Fogh Rasmussen. In 2006 the three parties arrived at an agreement that generated another Circulation Document. This document (Danish Ministry of Refugees, Immigrants and Integration 2006) signalled further steps in a more restrictive direction. Applicants for naturalization should henceforth declare that they have not committed any criminal acts, and the requirements regarding conduct were tightened even further. A prison sentence of 18 months or more currently implies permanent exclusion from the opportunity to obtain citizenship through naturalization (Section 19). In addition, the applicant must be financially self-sufficient, in the sense that he or she should not have received any welfare benefits for more than one of the last five years (Section 23). ${ }^{\mathrm{g}}$ A further change involved the condition that the applicant's familiarity with Danish society, culture and history should be documented in the form of a separate indfødsretsprøve (citizenship test). This test is a supplement to the even more rigid language proficiency requirements that have come into force by raising the standards defined by the regulations from 2002. The possibilities for exemptions have been reduced and are only granted to applicants who can document that they suffer from 'a physical or mental illness of a very grave character' (Section 24).

The new language proficiency requirements were subject to strong criticism in the Danish public, but the agreement between the government and the Danish People's Party nevertheless remained in force (Ersbøll, 2006). While the reductions in the number of naturalizations following the amendments made in 2002 were of a temporary nature and later rose to previous levels, the new regulations appear to have resulted in a permanent reduction. Many immigrants are dependent on social transfers and are not integrated into the labour market, and thereby face problems in fulfilling the requirement for self-sufficiency. Furthermore, the language proficiency requirements have become so strict that certain groups will be unable to comply with them, even if they expend considerable effort in the process.

The trend towards restriction came to an end after the new Danish centre-left government came into office in autumn 2011. According to Ersbøll (2013) a new trend towards facilitation of acquisition of citizenship is currently emerging, and it even includes the controversial question of dual citizenship: In June 2014, a new law which permits foreigners to become Danish citizens without having to renounce was allegedly approved by the Danish Parliament. The new law will also allow former Danish citizens who have given up their citizenship for another, to be able to reclaim it. The law change is expected to come into force in the summer of $2015 .^{\text {h }}$

Acceptance of dual citizenship will probably change the public perception of Denmark's strict approach to immigration. Nonetheless, the Danish nationality law will still be the 
most restrictive in the Nordic region. The gradual tightening of Danish nationality legislation in the early 2000s can be perceived as a reinforcement of the idea of citizenship as a reward for a complete and successful integration into Danish society. New requirements for loyalty and allegiance to the country have been introduced, the required time of residence has been made longer and financial self-sufficiency is still required. To many applicants, these requirements may appear as insurmountable barriers. Nevertheless, new Danish citizens are undeniably well equipped to cope with life in Denmark, in terms of language skills, financial situation and in terms of labour market participation. However, the restrictive legislation has clearly raised the threshold for citizenship acquisition. Even an acceptance of dual citizenship will not in itself increase the number of non-citizens with access to the privilege of citizenship in the years to come.

\section{Norway in an intermediate position}

Seen in light of the Swedish Citizenship act from 2001 and the amendments to Danish naturalization policy during recent years, the process leading up to the new Norwegian Nationality Act of 2005 is quite interesting. Liberal as well as restrictive views can be identified in the preparatory documents, along with rhetorical elements that are similar both to the Swedish and Danish debates. While the Swedish committee was characterized by basic consensus, and its proposals were included in full in the government's bill and also later in the text of the act, the white paper from the Norwegian committee (NOU 2000: 32) is characterized by dissenting opinions in several aspects. The committee majority recommended a liberalization of the law, including acceptance of dual citizenship, and their arguments were similar to their Swedish counterparts. The minority, however, drew on arguments from the Danish debate, and wished to preserve the principle of unitary citizenship and raise the barriers to naturalization. Interestingly, it was the views of the minority that were included most prominently in the proposal for a new act on citizenship submitted by the CentreRight Government in 2004 (Ot.prp. nr. 41 (2004-2005)). The proposal was enacted 1 September 2006 and remains in force, with a few minor changes since the enactment.

As noted above, the Norwegian committee split into a majority and a minority over the question of dual citizenship. The majority claimed that the factors that traditionally have been assessed as disadvantages of dual citizenship from the perspective of the state - military draft in two countries, problems related to diplomatic protection and concerns for national security - currently should be perceived as being of minor importance. Even the special advantages for individuals of having two formal citizenships, such as having two passports and being eligible for parliament in two countries, was seen by the committee as having few practical implications, as long as there already are persons with two passports in the population and that the right to vote and eligibility in local elections are granted to persons who have been resident in the country for at least three years. As regards the concerns for sufficient affiliation to the country and the potential for divided loyalties, the committee stated that immigrants invariably would preserve an attachment to the home country and often will wish to maintain contact: 'These kinds of ties and interests will not disappear when the person becomes a Norwegian citizen' (NOU 2000:32, p. 89). This line of argument is strikingly similar to what can be found in the Swedish report, and like their Swedish colleagues, the majority of the Norwegian committee endorsed acceptance of dual citizenship. 
The committee minority, on the other hand, claimed that the views of the majority were based on a too individualistic notion of citizenship, and that acceptance of dual citizenship was likely to erode traditional Norwegian ideals of equality. Insofar as cases of dual citizenship are caused by special concerns and practical circumstances beyond the control of the authorities, the special advantages of dual citizenship would appear as an aberration which would be unacceptable to most Norwegian citizens: 'Giving further priority to individualistic principles by normalizing dual citizenship risks undermining the political unity that characterizes Norway' (NOU 2000:32, p. 93).

Although the committee majority wished to introduce acceptance of dual citizenship and most of the entities consulted during the consultative round also agreed to this, the Norwegian Government endorsed the viewpoints of the committee minority. In the proposal for the act, submitted in 2004, the Government emphasizes that:

Citizenship is a key symbol of affiliation and loyalty to the Norwegian political community and the principles on which this community is based. The receipt of a Norwegian citizenship represents a formalization of the implicit social contract between the society and the citizen. A principle of dual citizenship represents a certain contrast to this ideal point of departure. The right to participate directly in national politics implies that the primary political loyalty ought to be made clear (Ot. prp. nr. 41 (2004-2005), p. 40).

The Norwegian Government hence chose to follow the Danish example on the question of dual citizenship. In other respects, however, the law has been liberalized. For instance, the acquisition of citizenship through naturalization has been made into a general entitlement, given that the conditions are fulfilled. The previous system, which was based on discretionary judgement, has thereby been formally abandoned. Although this may appear to be more liberal than the Swedish practice, there is still a need to take a closer look at what in fact is required for a person to be able to exercise this entitlement. As in Sweden, the applicant must document his or her identity and have a permanent residence permit. Furthermore, the applicant must be resident and stay resident in the country and not be convicted of any criminal actions. As regards the required time of residence, Norway maintains an intermediate position between Sweden and Denmark, in requiring seven years of residence during the last ten years. ${ }^{i}$ Since Norway has maintained the principle of unitary citizenship, the applicant must have renounced his or her previous citizenship before an application can be approved.

The question of dual citizenship was a source of internal strife in the Norwegian committee. However, the minority submitted dissenting views also with regard to the introduction of requirements for language proficiency and knowledge of Norwegian society as mandatory conditions for acquisition of Norwegian citizenship through naturalization. None of the previous Norwegian nationality acts had included an explicit requirement for language proficiency, although the preparatory documents for these acts stipulate that language skills should be considered during the discretionary procedure used for the assessment of applications for citizenship. After the 1950 act, the language requirement had in practice gradually disappeared (NOU 2000:32, p. 135).

Since Norway already had a comprehensive programme of language training for newly arrived immigrants, the committee's majority could see no need for a further 
language test as a condition for granting citizenship. The arguments are similar to what is found in the Swedish report: Language skills are regarded as a key precondition for active participation in society, but since a language test could have varying effects for different individuals, this 'could serve to exclude from citizenship a number of groups that for various reasons do not possess adequate Norwegian language skills after seven years of residence' (NOU 2000:32, p. 141). Establishing requirements for knowledge of Norwegian society was rejected on the basis of similar arguments.

The committee minority, on the other hand, claimed that requirements for language skills and knowledge of Norwegian society should be introduced. This was done with reference to the Norwegian language community as being small and vulnerable, and that the Norwegian language therefore ought to be 'nurtured and defended'. Absence of any knowledge of Norway's democratic traditions would further be perceived as an 'expression of a lack of respect' for the political community that the applicant wishes to join (NOU 2000:32, p. 142).

On the issue of requirements for language proficiency and knowledge of society, the Norwegian Government chose a middle road between the majority and minority in the committee. Since 2003, immigrants aged 16-55 who have been granted a work and residence permit are already under an obligation to undergo 600 hours (previously 300 hours) of Norwegian language training. Documented completion of this training has now been included as a condition for naturalization, and the government accordingly followed the minority's recommendation in this question. However, the views of the committee majority were partly followed on the issue of knowledge of society. The new act does not define any requirements for knowledge of Norwegian society or familiarity with Norwegian democratic forms of governance, but the 600 hours of mandatory training comprise 50 hours of social studies, which in practice constitutes an indirect requirement.

A final aspect to be addressed in this review of the Norwegian act is the assessments pertaining to the oath of allegiance and a ceremony to mark completed naturalization. The first Norwegian act regulating citizenship, enacted in 1888, included an oath of allegiance to the Norwegian constitution as a precondition for acquisition of citizenship. This requirement was also included in the acts from 1924 and 1950, but was abolished in 1976, since the arrangement was regarded as an unnecessary formality (Hagelund \& Reegård, 2011). The committee saw no reason to reintroduce an oath of allegiance, but proposed that voluntary ceremonies in accordance with the Swedish model should be considered (NOU 2000:32, p. 183). In the period subsequent to the submission of the committee's report it became clear that a number of the entities consulted during the consultative round took a positive view of the introduction of a dignified ceremony, and to the possibility of swearing an oath of allegiance in this context. The Norwegian Government therefore chose to disregard the committee's views on this issue, and today ceremonies are arranged for new Norwegian citizens, including an oath of allegiance. However, the entire process rested on the assumption that participation in the ceremony should be voluntary (Ot. prp. nr. 41, (2004-2005), p. 51).

Summing up, the Norwegian Nationality Act og 2005 is highly ambiguous. On the one hand, the principle of unitary citizenship has been maintained, naturalization is conditioned on requirements for language proficiency, and an oath of allegiance has been reintroduced as an element of what in the Norwegian context is an innovation: A 
ceremony for persons who have been granted citizenship. On the other hand, all those who fulfil the conditions for naturalization are currently entitled to Norwegian citizenship, a fact which represents a significant curtailment of the power of the authorities to exercise discretionary judgement. Furthermore, the oath of allegiance is mandatory only for those who participate in the voluntary ceremony, which leaves each and every one free to assess its value. The Norwegian Nationality Act thereby signals an attempt to strike a balance between liberal values of individual freedom on the one hand, and acceptance of certain common national values, defined by the majority society, on the other. Table 1 summarizes the key provisions in the nationality legislation of the three Scandinavian countries.

\section{Discussion}

\section{Social cohesion in the multicultural nation}

A striking feature of the amendments to nationality law in Sweden, Denmark and Norway is the tendency to regard citizenship in the context of broader integration processes. Interestingly, however, the relatively similar challenges faced by Norway, Sweden and Denmark in the field of integration policy appear to have given rise to larger political differences between them - in integration policy as well as in nationality law (Brochmann \& Hagelund, 2012). How may we explain the major differences within Scandinavian nationality legislation?

As noted above, a major tradition in the citizenship literature has perceived nationality legislation as a more or less direct reflection of nationhood. This position has particularly been influenced by the seminal work of Rogers Brubaker (1992), in which the different nationality legislations in France and Germany are analysed in a historical perspective. Brubaker shows how these legal traditions should be interpreted in light of the historical process of nation-building, and his main point is that nationality law has a tendency to remain stable due to the normative strength of national selfconceptions.

Table 1 Overview of key provisions in the nationality legislation of the Scandinavian countries

\begin{tabular}{|c|c|c|c|}
\hline Key Provisions & Sweden & Norway & Denmark \\
\hline Acceptance of dual citizenship & Yes & No & $\mathrm{No}^{*}$ \\
\hline Required time of residence & 5 years & 7 years & 9 years \\
\hline $\begin{array}{l}\text { Ceremony to mark } \\
\text { naturalization }\end{array}$ & Voluntary & Voluntary & Voluntary \\
\hline Oath of allegiance & No & $\begin{array}{l}\text { Compulsory when attending } \\
\text { ceremony }\end{array}$ & Compulsory \\
\hline $\begin{array}{l}\text { Requirement for language } \\
\text { proficiency }\end{array}$ & No & $\begin{array}{l}\text { Indirectly, in the form of } \\
\text { documented language training }\end{array}$ & $\begin{array}{l}\text { Yes, separate language } \\
\text { exam }\end{array}$ \\
\hline $\begin{array}{l}\text { Requirement for knowledge of } \\
\text { society }\end{array}$ & No & $\begin{array}{l}\text { Indirectly, as part of language } \\
\text { training }\end{array}$ & $\begin{array}{l}\text { Yes, separate citizenship } \\
\text { exam }\end{array}$ \\
\hline $\begin{array}{l}\text { Requirements for financial self- } \\
\text { sufficiency }\end{array}$ & No & No & Yes \\
\hline $\begin{array}{l}\text { Right to citizenship when } \\
\text { conditions are fulfilled }\end{array}$ & $\begin{array}{l}\text { Several } \\
\text { groups, not } \\
\text { all }\end{array}$ & Yes & $\begin{array}{l}\text { Only second-generation } \\
\text { Nordic citizens }\end{array}$ \\
\hline
\end{tabular}

*Allegedly, Denmark will accept dual citizenship in the summer of 2015. 
It is indeed tempting to conclude that the differences in nationality legislation observed among Norway, Sweden and Denmark are expressions of diverging national self-conceptions. In addition to providing formal rights, citizenship undoubtedly also has a symbolic dimension: Nationality legislation is the regulation of one of the constituting elements of the nation-state - its population. Rules for acquisition of citizenship define the framework for inclusion and exclusion in the symbolic community represented by the nation. As such, nationality law can be interpreted as an implicit expression of a national self-representation. If the relevance of this symbolic aspect of citizenship is accepted, the logical extension of the argument would be to interpret the differences between the Scandinavian countries as reflections of divergent conceptions of nationhood.

Since Brubaker presumes that stability is an important hallmark of nationality law, however, the major changes in Scandinavian legislation during recent years may indicate that this perspective has lost some of its relevance. Indeed, Brubaker has encountered plenty of opposition: Soysal (1994) claimed two decades ago that we were approaching a postnational age in which the whole idea of national citizenship would lose its relevance. Hansen and Weil (2001) and Joppke (2007) have, although in a less polemic fashion, also been highly critical of the explanatory power that Brubaker ascribes to the nation, suggesting instead that a general movement towards liberalization is occurring. Along the same lines, Kivisto and Faist (2007; see also Faist 2007) have argued that international migration and increased transnationalism will lead to liberalization of nationality laws and particularly to an acceptance of the principle of dual citizenship.

But it is also hard to observe such homogenous processes of liberalization in European nationality legislation. A comparative study of rules of acquisition of citizenship in $15 \mathrm{EU}$ countries demonstrates that trends toward liberalization exists side by side new and more restrictive trends (Bauböck et al., 2006). And in Scandinavia, as this article has showed, the differences are striking. Sweden accepts dual citizenship and requires five years of residence for naturalization, but no requirements are made for language proficiency, knowledge of society or financial self-sufficiency. In Denmark, dual citizenship now seems to be accepted, but the requirements for naturalisation are still many: the required time of residence has been increased to nine years, and requirements are imposed with regard to financial self-sufficiency, knowledge of Danish culture, society and history, as well as documented language skills at a very high level. In Norway, unitary citizenship remains the main principle in Norwegian legislation, the required time of residence is seven years, and requirements for language proficiency have been introduced. However, applicants for citizenship do not yet need to pass any examinations (although this is currently being discussed) and Norway does not require financial self-sufficiency. Clearly, the divergent development of citizenship policies in the Scandinavian countries demonstrates that a general process of liberalization is not taking place.

May then the concept of national self-conceptions be relevant after all? The fact that an almost one hundred year old tradition of wide-ranging collaboration in the field of nationality law in Scandinavia was abandoned in 1979 may reflect that national interests were seen as more important than Scandinavian cooperation in the wake of postwar migration. Brochmann (2002) has pointed out that immigration indirectly 'puts the receiving society into perspective: its history and traditions, its political values, as well 
as its self-reflection and identity' (2002:58, author's translation). In other words, it might be the case that post-war migration activated latent differences in the conceptions of nationhood in the Scandinavian countries, which in turn may have weakened the incentives for collaboration in the field on nationality law and prepared the ground for the various roads that these countries gradually have followed in their immigration policies in general since the 1970s (see Brochmann \& Seland, 2010 for a similar argument). If that is the case, today's citizenship policies are better indicators of the different ideas of nationhood characterising the Scandinavian countries than the historical collaboration on citizenship issues in the first half of the $20^{\text {th }}$ century.

It is however important to keep in mind that all amendments implemented in Scandinavian nationality laws in recent years have been made with the same overall purpose: a more successful integration of immigrants in the receiving society. The large differences in the content of citizenship policies thus reveal the fact that we do not know much about the actual relationship between social integration and acquisition of a formal citizenship. In the international debate on these issues, it is often taken for granted that liberal integration policies and easy access to a formal citizenship increase social and political integration (e.g. Banting \& Kymlicka, 2006; Bloemraad, 2006). Yet some studies point to a potential 'trade-off' between liberal policies and socioeconomic outcomes (e.g. Koopmans, 2010), suggesting instead that restrictive and more 'demanding' approaches lead to more successful immigrant integration. The lack of a convincing demonstration of the integration effects' of citizenship acquisition may help explaining the polarized character of today's nationality laws. Across Europe, a quest for some basic values that can contribute to establishing solidarity and feelings of belonging in multicultural nation-states is currently taking place, but through what measures this social cohesion best can be achieved is a contested issue. In many countries, this process results in more demanding integration policies and more exclusive nationality laws. At the one hand, this probably reflects a wish to create 'good citizens' that are enabled to integrate into the majority society. On the other hand, upgrading the national community may also give rise to more prominent lines of division between those with and without access to the privileges of citizenship.

\section{Conclusion}

The development of nationality legislation in the Scandinavian countries has moved away from long-term endeavours to establish homogeneity towards the striking differences that characterize the countries' regulations today. In the early 21st century, Sweden and Denmark occupy opposite ends of a scale ranging from liberal to restrictive nationality law, with Norway in an intermediate position. A common feature of the debates associated with amendments to nationality legislation in the Scandinavian countries is that formal citizenship is seen in the context of more wide-ranging integration processes. While the liberal Swedish regulations are intended to function as an instrument for integration into Swedish society, Denmark regards citizenship as a reward for a completed integration. By comparison, Norwegian citizenship is granted on the basis of an initiated process of integration; inclusion into the national community is conditioned on a documented willingness to integrate.

Drawing linkages between citizenship and integration - between legal and social belonging in a nation-state - is not a Scandinavian phenomenon, but should rather be 
regarded as a feature of a wider European development. At the same time, the role ascribed to citizenship in the integration process by the Scandinavian countries demonstrates the range of political opportunities offered by the concept of integration in the current European context. What the three countries appear to have in common, however, are attempts to establish a framework of cohesion and equality, which could serve to integrate a diverse population into a social community. In Sweden, this is restricted to an expectation of democratic participation. In Denmark, national authorities have come close to defining adaptation of the majority culture as a precondition for inclusion into the nation, whereas Norway has assumed a somewhat wavering intermediate position. These different approaches to citizenship and integration in the Scandinavian region demonstrate the continued power of the nation state to determine the conditions for inclusion and exclusion within its borders. Although static concepts of nationhood cannot account for the recent changes in nationality law in the Scandinavian countries, ideas about national identity and social cohesion are still highly influential in determining the content of nationality law.

\section{Endnote}

a Jus sanguinis and jus soli are alternative principles for automatic acquisition of citizenship at birth. In its pure form, jus sanguinis implies that a newborn child will be granted citizenship if one of the parents possesses such citizenship, while jus soli implies that any child born inside the territorial boundaries of the state automatically is granted citizenship of that state.

b All quotations from the public documents referred to in this article are translated to English by the author.

${ }^{c}$ For Nordic citizens the required time of residence is four years, while stateless persons or persons with refugee status are subject to a requirement of four years' residence, cf. Lag om svensk medborgarskap (2001:82) Section 11, subsections 4 a) and b).

${ }^{d}$ In the preparatory documents to the Swedish act (SOU 1999:34), the committee claims that Swedish authorities would be unlikely to accept dual citizenship without first consulting the other Nordic countries. However, according to the Chair of the Norwegian committee, Mr Jan Skåre, such requests were never made (cf. Minutes from the meeting between the Norwegian parliamentary committee and representatives of the other Nordic countries, 14 January 2000).

e Requirements for documentation of actual dissolution had previously been unnecessary, since this happened automatically upon acquisition of citizenship in another Nordic country. When Sweden accepted dual citizenship in 2001 the rule of automatic dissolution was deleted, but the new Danish requirements for documentation neutralized the consequences of the Swedish turnaround with regard to Denmark (Ersbøll 2006:128).

${ }^{\mathrm{f}}$ Citizens of the other Nordic countries can apply for citizenship after two years of continuous residence, while registered refugees and stateless persons can apply after eight years (Section 7).

${ }^{\mathrm{g}}$ In 2013, this requirement was somewhat liberalized. Today, reception of social benefits for up to two and a half years within the last five years is accepted (Ersbøll, 2013).

h The New Copenhagen Post, June 4 2014: http://cphpost.dk/dual-citizenship-approvedby-danish-parliament/. 
i The conditions for acquisition of citizenship on the basis of application (naturalization) are defined in Section 7 of the Norwegian Nationality Act (2005:51). It should be added that Norway, Sweden and Denmark have different definitions of the required time of residence. In Denmark and Norway, time of residence is defined as the time a person has legally stayed in the country. In Sweden, time of residence is defined on the basis of a principle of fixed residence, meaning that temporary residence permits are not counted (Ot.prp. nr. 41 (2004-2005), p. 93). This implies that in many cases, there will be no major differences between the requirements for time of residence that in practice are applied in Sweden and Norway respectively.

\section{Author's contributions}

AHM carried out the comparative analysis and is the sole author of this article.

\section{Authors' information}

Arnfinn H. Midtbøen holds a ph. d in sociology from the University of Oslo, Norway, and is a Senior Researcher Fellow at the Institute for Social Research, also in Oslo. His research interests include citizenship and integration policies, ethnic discrimination in labour markets, and incorporation patters among descendants of immigrants in Europe. Recent publications include The Invisible Second Generation? Statistical Discrimination and Immigrant Stereotypes in Employment Processes in Norway' (Journal of Ethnic and Migration Studies, 2014) and 'The Context of Employment Discrimination: Interpreting the Findings of a Field Experiment' (British Journal of Sociology 2014).

\section{Acknowledgements}

Many thanks to Grete Brochmann and the Journal's two anonymous referees for valuable comments to a previous draft of this article.

Received: 31 July 2014 Accepted: 17 November 2014

Published online: 21 May 2015

\section{References}

Banting, K, \& Kymlicka, W. (2006). Multiculturalism and the Welfare State. Recognition and Redistribution in Contemporary Democracies. Oxford: Oxford University Press.

Bauböck, R, Ersbøll, E, Groenendijk, K, \& Waldrauch, H (Eds.). (2006). Acquisition and Loss of Nationality: Policies and Trends in 15 European Countries. Volume 1: Comparative Analysis. Amsterdam: Amsterdam University Press.

Bernitz, H. (2012). Country Report: Sweden. EUDO Citizenship Observatory. Badia Fiesolana: European University Institute. Bernitz, HL, \& Bernitz, H. (2006). Sweden. In R Bauböck, E Ersbøll, K Groenendijk, \& H Waldrauch (Eds.), Acquisition and Loss of Nationality: Policies and Trends in 15 European Countries. Volume 2: Country Analysis. Amsterdam: Amsterdam University Press.

Bloemraad, I. (2006). Becoming a Citizen: Incorporating Immigrants and Refugees in the United States and Canada. Berkeley and Los Angeles: University of California Press.

Brochmann, G. (2002). Statsborgerskap, medborgerskap og tilhørighet [Citizenship and Belonging]. In G Brochmann, T Borchgrevink, \& J Rogstad (Eds.), Sand i maskineriet. Makt og demokrati i det flerkulturelle Norge [Sand in the Machinery. Power and Democray in Multicultural Norway]. Oslo: Gyldendal Akademisk.

Brochmann, G, \& Hagelund, A. (2012). Immigration Policy and the Scandinavian Welfare State, 1945-2010. Houndmills: Palgrave Macmillan.

Brochmann, G, \& Seland, I. (2010). Citizenship policies and ideas of nationhood in Scandinavia. Citizenship Studies, 14(4), 429-443. doi:10.1080/13621025.2010.490037.

Brubaker, R. (1992). Citizenship and Nationhood in France and Germany. Cambridge: Harvard University Press.

Brubaker, R (Ed.). (1989). Immigration and the Politics of Citizenship in Europe and North America. New York: University Press of America.

Danish Ministry of Refugees, Immigrants and Integration. (2006). Cirkulæreskrivelse nr. 9 af 12.01 .2006 om naturalisation [Circular Document No. 9 on Naturalisation]. Retrieved from https://www.nyidanmark.dk/NR/rdonlyres/0271E58F0CA9-4492-B87F-5C905FF7FDEB/0/cirkulaereskrivelse_nr_9_12_januar_2006_engelsk.pdf.

Danish Ministry of Refugees, Immigrants and Integration. (2002). Cirkulæreskrivelse nr. 55 af 12.06 .2002 om dansk indfødsret ved naturalisation [Circular Document No. 55 on Danish Citizenship by Naturalisation]. Retrieved from: http://eudo-citizenship.eu/NationalDB/docs/DEN\%20CIR\%20No\%2055\%202002\%20\%28original\%29.pdf.

Ersbøll, E. (2003). Statsborgerskap - medborgerskap - europæisk konvergens - nordisk divergens [Citizenship - European Convergence - Nordic Divergence]. Nordisk tidsskrift for menneskerettigheter, 2, 147-163.

Ersbøll, E. (2006). Denmark. In R Bauböck, E Ersbøll, K Groenendijk, \& H Waldrauch (Eds.), Acquisition and Loss of Nationality: Policies and Trends in 15 European Countries. Volume 2: Country Analysis. Amsterdam: Amsterdam University Press.

Ersbøll, E. (2013). Country Report: Denmark. EUDO Citizenship Observatory. Badia Fiesolana: European University Institute.

Faist, T. (2007). Dual Citizenship: Change, Prospects, and Limits. In T Faist (Ed.), Dual Citizenship in Europe. From Nationhood to Societal Integration. Cornwall: Ashgate.

Favell, A. (1998). Philosophies of Integration: Immigration and the Idea of Citizenship in France and Britain. London: Macmillan Press. 
Hagelund, A, \& Reegård, K. (2011). 'Changing teams': a participant perspective on citizenship ceremonies. Citizenship Studies, 15(6-7), 735-748. doi:10.1080/13621025.2011.600087.

Hailbronner, K. (2006). Nationality in public international law and European law. In R Bauböck, E Ersbøll, K Groenendijk, \& H Waldrauch (Eds.), Acquisition and Loss of Nationality: Policies and Trends in 15 European Countries. Volume 1: Comparative Analysis. Amsterdam: Amsterdam University Press.

Hansen, R, \& Weil, P. (2001). Introduction: Citizenship, Immigration and Nationality: Towards a Convergence in Europe? In R Hansen \& P Weil (Eds.), Towards a European Nationality: Citizenship, Immigration and Nationality Law in the EU. Palgrave: Basingstoke.

Holm, LK. (2006). Migration, nationalt tilhørsforhold og statsborgerskab: Forskelligt syn på dobbelt statsborgerskab i Danmark og Sverige [Migration, National Belonging and Citizenship. Divergent Views on Dual Citizenship in Denmark and Sweden]. In U Hedetoft, B Petersson, \& L Sturfelt (Eds.), Bortom stereotyperna? Invandrare och integration i Danmark och Sverige [Beyond the Stereotypes? Immigrants and Integration in Denmark and Sweden]. Göteborg: Makadam Förlag.

Joppke, C. (2007). Transformation of Citizenship: Status, Rights, Identity. Citizenship Studies, 1, 37-48. doi:10.1080/ 13621020601099831.

Kivisto, P, \& Faist, T (Eds.). (2007). Dual Citizenship in Global Perspective. From Unitary to Multiple Citizenship. Hampshire: Palgrave Macmillan.

Koopmans, R. (2010). Trade-Offs between Equality and Difference: Immigrant Integration, Multiculturalism and the Welfare State in Cross-National Perspective. Journal of Ethnic and Migration Studies, 36(1), 1-26. Doi:10.1080/13691830903250881.

Mouritsen, P. (2013). The resilience of citizenship traditions: Civic integration in Germany, Great Britain and Denmark. Ethnicities, 13(1), 86-109. doi:10.1177/1468796812451220.

Nordhaug, S. (2000). Tilknytning og privilegier: En studie i fremveksten av norsk statsborgerrett [Belonging and Privileges (The Emergence of Citizenship Rights in Norway]). NTNU, Trondheim: MA Thesis.

NOU 2000: 32. Lov om erverv og tap av norsk statsborgerskap (Statsborgerloven) [Law on Acquisition and Loss of Citizenship (The Citizenship Law)]. Oslo: Norwegian Ministry of Justice and the Police (2000). Retrieved from http:// www.regjeringen.no/nb/dep/jd/dok/nouer/2000/nou-2000-32.html?id=143396

Ot.prp. nr. 41. (2004-2005). Om lov om norsk statsborgerskap (Statsborgerloven). [Proposition to the Norwegian Storting regarding the Citizenship Act]. Oslo: Norwegian Ministry of Local Government and Regional Development. Retrieved from http://www.regjeringen.no/nb/dep/kmd/dok/regpubl/otprp/20042005/otprp-nr-41-2004-2005.html?id=395901

Perchinig, B, \& Bauböck, R. (2006). Preface. In R Bauböck, E Ersbøll, K Groenendijk, \& H Waldrauch (Eds.), Acquisition and Loss of Nationality: Policies and Trends in 15 European Countries. Volume 2: Country Analysis. Amsterdam: Amsterdam University Press.

Soysal, Y. (1994). Limits of Citizenship. Chicago: University of Chicago Press.

SOU 1999:34. Svenskt medborgarskap. Slutbetänkande av 1997 års medborgarskapskommitté [Swedish Citizenship. Report from the Citizenship Commitee of 1997]. Stockholm: Swedish Ministry of Culture. Retrieved from http:// www.regeringen.se/sb/d/108/a/2401

\section{Submit your manuscript to a SpringerOpen ${ }^{\circ}$} journal and benefit from:

- Convenient online submission

- Rigorous peer review

- Immediate publication on acceptance

- Open access: articles freely available online

- High visibility within the field

Retaining the copyright to your article 